\title{
Strengthening Regional Financial Cooperation IN EAST ASIA
}

The 1997-98 financial crisis prompted East Asian economies to realise the potential benefits of installing stronger cooperative mechanisms for crisis prevention, management and resolution. This paper argues that a regional financial architecture needs to be firmly established in East Asia, outlines recent developments in financial cooperation in the region, and provides possible directions for the future. We recommend a more effective surveillance process and consider the option of creating a common pool of foreign exchange reserves to allow flexible financial support at times of crises and contagion while minimising the problem of moral hazard. The arrangement must be consistent with the global framework; in particular, it must involve international creditors from outside the region for crisis management and resolution. We suggest that exchange rate regime choice should be coordinated at the regional level, with a long-term vision of regional monetary integration.

\section{Introduction}

The financial crisis of 1997-98 highlighted the importance of regional financial cooperation in East Asia. Before the crisis, increasing economic interdependence through trade, direct investment and finance in the region was not matched by the development of mechanisms and institutions for regional financial cooperation. There is a strong perception in the region that more effective regional institutions and frameworks might have prevented the crisis or at least allowed it to be better managed. The crisis prompted the region's economies to realise that stronger regional cooperative institutions could help to prevent and manage crises in a way that complements the role of the International Monetary Fund (IMF) in the global framework.

This paper argues that a new regional financial architecture needs to be firmly established in East Asia, outlines recent developments in financial cooperation in the region, and provides possible directions for the future. We recommend that the regional surveillance process be made more effective, and consider the option of creating a common pool of foreign exchange reserves to allow more flexible financial support at times of crises and contagion while minimising the 
problem of moral hazard. The arrangement must be consistent with the global framework; in particular, it must ensure private sector involvement for crisis management and resolution at the global level. In this paper we suggest that exchange rate regime choice should be coordinated at the regional level, with a long-term vision of regional monetary integration.

The organisation of the paper is as follows. First, we summarise some lessons to be learned from the East Asian crisis. Then we discuss the logic of financial cooperation at the regional level in East Asia, emphasising the increasing economic interdependence among the regional economies. Next, we outline several initiatives for financial cooperation, including the ASEAN+3 Economic Review and Policy Dialogue Process and the formation of a network of bilateral swap arrangements under the Chiang Mai Initiative (CMI). This section also identifies future challenges for regional financial cooperation. Finally, we provide some concluding remarks.

\section{Lessons from the East Asian Crisis}

\section{The1997-98crisis}

The East Asian financial crisis of 1997-98 was triggered by massive reversals of capital flows and contagion. Though deeper, structural causes of crises vary, there was a common factor across countries: imprudently managed domestic financial institutions over-extended loans to corporations that in turn invested the borrowed funds in unproductive projects. Furthermore, an initially benign-looking currency crisis evolved into a full-blown economic crisis due to the mutually reinforcing impacts of currency depreciation, financial sector deterioration, and corporate sector distress. Essentially the crisis was the result of interactions between the forces of financial globalisation and domestic structural weaknesses (World Bank 1998, 2000).

\section{F orces of financial gl obalisation}

The affected countries had liberalised international capital flows and had been integrated with the international capital markets before the crisis. Many East Asian economies clearly benefited from the liberalisation and globalisation of financial markets. From the mid-1980s to the mid-1990s, large inflows of capital, particularly long-term capital such as foreign direct investment (FDI), helped finance the region's rapid economic development and growth. In the several years leading up to the crisis, however, countries had received large inflows of capital in the financial and corporate sectors, particularly in the form of unhedged short-term capital. 
As a result, the ratios of short-term external debt to foreign exchange reserves had risen to levels greater than one. When market perceptions changed rapidly in 1997, these economies saw sudden outflows of capital and consequent large downward pressures on the currency. The currency crisis was triggered by the sudden reversal of capital flows, which is why the crisis is often called the 'capital account crisis' (Yoshitomi and Shirai 2000; Kawai et al. 2001).

Regional contagion of the crisis was spectacular. The Thai baht crisis spread to Malaysia, Indonesia, the Philippines and eventually South Korea within a few months. At a later stage, Hong Kong was also affected, but the authorities managed successfully to contain its impact using unconventional policy measures.

\section{Domestic structural weaknesses}

The crisis-hit countries also had domestic structural weaknesses. Some foreign capital was intermediated by domestic financial institutions that extended loans to domestic sectors, including non-tradable real estate and construction; some found its way directly into domestic corporations. Investment in real estate and other assets contributed to the generation of asset bubbles, which left financial institutions with serious problems of non-performing loans when the bubble ultimately burst. In this way, financial institutions that intermediated foreign capital to domestic sectors were exposed to currency and maturity mismatches. Domestic corporations that were highly leveraged were also exposed to interest and exchange rate shocks. Inadequate regulatory and supervisory frameworks had left banks and corporations with imprudent financial management and, more generally, weak corporate governance. Steep exchange rate depreciation, high interest rates and tight budgets, induced by the eruption of a currency crisis in 1997, aggravated financial and corporate sector distress and led to a sharp contraction of economic activity in 1998.

\section{Reform of theinternational financial architecture}

\section{Lessons}

There are at least two important lessons from this experience. First, greater attention needs to be paid to managing the forces of financial globalisation, particularly in a world of rapid shortterm capital flows. Until the crisis, implications of the scope and magnitude of short-term capital flows were not fully understood by international investors, policymakers of the borrowing countries, or international financial institutions. More fundamentally, there was a lack of 
concern over the volatile nature of capital flows, the need for monitoring capital flows, and the need to respond to rapid capital flows. Management of financial globalisation requires frameworks that reduce capital flow volatility and enhance domestic capacity to manage undesirable impacts of globalisation.

Second, emerging market economies need to strengthen domestic economic systems, in particular their financial and corporate sectors. This task requires the establishment of effective regulatory and supervisory frameworks for the better management and governance of financial institutions and corporations. Specifically, economies in the region need to improve banks' assetliability management capacity so as to avoid over-extension of loans and excessive currency and maturity mismatches; improve corporations' financial management capacity so as to maintain their sound financial discipline; and develop sound capital markets so as to provide alternative financing sources for corporations. If the domestic economic system becomes robust and resilient, a crisis could be prevented, or its impact on the economy would be mitigated even if a crisis occurred.

Reflecting on these lessons, there has been an increasing recognition that putting effective mechanisms in place to manage the forces of globalisation and to strengthen domestic economic systems is key to crisis prevention, management and resolution. Various efforts to reform the functioning of international financial markets and to strengthen domestic economic underpinnings have been made under the title of the 'international financial architecture'. ${ }^{1}$

\section{Strengthening theinternational financial system}

At the global level, various reforms for crisis prevention, management and resolution have been proposed and some have been put in place.

First, the workings and functions of the IMF have been strengthened. In particular, the IMF has increased its liquidity position. Its usable resources - the amount it can lend to member countries in financial need-doubled from SDR54 billion in 1998 to SDR110 billion in 2001. Its stock of net uncommitted usable resources - usable resources less resources committed under current arrangements and considered likely to be drawn, and less working balances of usable currencies - rose to SDR75 billion in 2001. In case its own resources are inadequate, the IMF can borrow up to SDR34 billion under the New Arrangements to Borrow and the General Arrangements to Borrow.

The IMF has also introduced new lending facilities to meet the greater financial needs of member countries at times of crises or as preventive measures. The Supplemental Reserve 
Facility was established in December 1997 and has been used in South Korea, Brazil, Argentina and Turkey. It provides large financial assistance, without access limit, to members facing exceptional balance of payments difficulties resulting from a sudden and disruptive loss of market confidence. The Contingent Credit Line was created in 1999 as a precautionary line of defence to help protect member countries in the event of an exceptional balance of payments need arising from the spread of financial crises, provided that the countries have pursued strong policies. Furthermore, the IMF has improved the transparency of its operations and policy deliberations. It has also decided to streamline its conditionality, particularly structural conditionality, in order to enhance ownership and effectiveness of its program.

Second, private sector involvement has been an important focus of reform. Given that the volume of private resources far exceeds that of official resources, private sector involvement is vital for crisis prevention and resolution. If official intervention were to bail out private investors without making them pay for their bad investment decisions, this would create a serious moral hazard problem. While private financial institutions decided to share the burden in helping crisis-hit countries in several cases, such as South Korea and Brazil, a definitive framework has yet to be developed. This is particularly the case for the restructuring of emerging economy bonds because of the large number and dispersion of bondholders involved.

The international community has begun to explore possible mechanisms for the debt restructuring of international sovereign bonds in the recognition that, at the time of a liquidity crisis, holders of sovereign bonds, along with other creditors, would need to contribute to the resolution of such crises. Two methods have been recommended: a contractual approach and a statutory approach. A contractual approach considers collective action clauses in sovereign bond contracts as a useful device for orderly resolution of crises; their explicit inclusion in bond documentation would provide a degree of predictability to the restructuring process. A statutory approach (Krueger 2002) attempts to create the legal basis - through universal treaty rather than through a set of national laws in a limited number of jurisdictions - for establishing adequate incentives for debtors and creditors to agree upon a prompt, orderly and predictable restructuring of unsustainable debt. ${ }^{2}$

Third, the G-20 and the Financial Stability Forum were created to broaden input into international financial policymaking, including systemically important developed and emerging market economies. A wide range of issues has been taken up, including highly leveraged institutions, offshore financial centres, and measuring vulnerabilities. But the reforms have not been fully satisfactory, owing to inadequate progress on private sector involvement, information disclosure by highly leveraged institutions, and use of contingent credit lines. 


\section{National efforts to strengthen domestic policies and institutions}

At the national level, there are efforts to strengthen domestic policy and institutional frameworks with an emphasis on macroeconomic management capacity and financial sector reform. Attention has focused particularly on the need to improve regulatory and supervisory frameworks in the financial system, to strengthen corporate governance, and to establish effective domestic insolvency procedures to deal with non-viable banks and corporations.

One of the principal tools for strengthening domestic policies and institutions is international best practice information in macroeconomic policymaking, financial sector regulation and supervision, and capital market infrastructure. Reports on the Observance of Standards and Codes (ROSCs), supported by various international organisations and agencies and adopted by the IMF in September 1999, cover 12 issues in three main areas. In the macroeconomic policy area, these include monetary and financial policy transparency, fiscal transparency, and special data dissemination standards in addition to the general data dissemination system. In the area of financial sector regulation and supervision, they include banking supervision, securities regulation, insurance supervision, payments systems, and anti-money-laundering. In the area of capital market infrastructure, they include corporate governance, accounting standards, auditing standards, and insolvency and creditor rights.

An important instrument is the Financial Sector Assessment Program (FSAP) supported jointly by the IMF and the World Bank. ${ }^{3}$ These processes are undoubtedly useful, but take time to be effectively implemented. And even if ROSCs are fully in place, crises may still occur.

\section{Creating a new regional financial architecture}

While the international community and emerging market economies have focused on global and domestic policy reforms, a well-designed regional framework can also contribute to the stability of the international financial system for three reasons. ${ }^{4}$ First, the global efforts are still inadequate and national efforts take more time to become effective. Second, there is increasing regional integration in trade, FDI and financial flows, so an effective regional framework for policy coordination and concerted action is desirable. Third, as economic contagion tends to begin with a geographic focus, a regional framework for financial cooperation to address crisis prevention, management and resolution is a logical way to proceed..$^{5}$ Thus it is important to improve regional financial architecture. 
A framework for regional financial cooperation may include three areas: regional surveillance and monitoring for crisis/contagion prevention; schemes to augment international liquidity for crisis management; and programs to assist crisis-affected countries to resolve the systemic impact of the crisis and accelerate the recovery process. Any regional framework must be consistent with the global framework in order to secure efficient responses to, and management and resolution of, future crises.

\section{Crisisprevention}

Regional information sharing, policy dialogue, consultation, surveillance and monitoring are instrumental to crisis prevention at the regional level. The process should include sharing of information on both macroeconomic and structural issues, such as monetary and exchange rate policies (including domestic and foreign assets and liabilities of the central banks), fiscal positions and debt management, capital flows and external debts, financial system conditions, and corporate sector developments. Monitoring capital flows at the regional level is particularly important. Prudential capital controls in the face of large inflows of short-term capital can be effective, as evidenced in the case of the Chilean experience in the 1990s. Developing a reliable early warning system is useful in detecting macroeconomic, external and financial sector vulnerabilities and preventing currency and financial crises in the future. With effective surveillance mechanisms in place, each economy in the region is expected to be under peer pressure to pursue disciplined macroeconomic and structural policies that are conducive to stable external accounts and currencies.

The consultation process may include efforts toward intra-regional exchange rate stability for economies that are highly integrated with, or complementary to, one another through trade and FDI. Avoiding competitive currency depreciation and mutually incoherent exchange rate policies is essential to preserving financial stability for mutually interdependent economies. These economies may wish to support an informal arrangement for stable exchange rates, introduce a formal mechanism for intra-regional exchange rate stability, or form a regional currency union.

\section{Crisismanagement}

Once an economy is hit by a currency crisis, appropriate policy responses and timely provision of international liquidity are needed to prevent the economy from slipping into a serious economic contraction of systemic proportions. The pace of liquidity disbursement at the global 
level may be slow in times of crisis or contagion, because of cumbersome bureaucratic processes and disagreements over policy conditionality. To avoid long delays and to augment globally available resources, a regional financing facility can help close the gap. This need is particularly apparent today because the IMF appears to be moving away from large-package operations to smaller packages with private sector involvement (PSI) (Kenen 2001). A financing facility that can rapidly mobilise a large amount of liquidity to head off a speculative attack is an obvious benefit if the attack is the result of irrational herd behaviour. For such a financing facility to be effective, its provision must be accompanied by appropriate policy measures to address the problem and restore investor confidence in the market.

When an effective PSI cannot be expected, an alternative might be a unilateral imposition of a standstill and/or a capital outflow control. Outflow controls have more frequently been a failure than a success in emerging market economies, but the Malaysian experience suggests that the deployment of this instrument can be useful in the right environment. In Malaysia, controls had a salutary effect mainly because they were temporary, supported by a strong macroeconomic framework, accompanied by bank and corporate restructuring, and implemented with credible supervision (see Kawai and Takagi 2003).

Some experts and academics have heavily criticised the recent IMF conditionality on certain East Asian countries, notably Indonesia, for not focusing sufficiently on containing the immediate currency crisis. ${ }^{6}$ A regional initiative, including liquidity support, may allow an economy hit by a currency attack or contagion to respond with more focused policy measures that are designed to address the immediate need for fire-fighting without compromising on moral hazard problems. This initiative, however, must be consistent with, and complementary to, the global framework, in order to exploit the synergy between the two, ensure policy coherence, and involve private creditors from outside the region.

\section{Crisisresolution}

To resolve a crisis, international efforts are needed to ensure that a crisis-affected economy returns to a sustainable growth path. In the face of a systemic crisis in the banking, corporate and social sectors, fiscal resource mobilisation is essential for the quick resolution of the crisis. Fiscal resources that are needed to recapitalise weak banks, facilitate corporate debt restructuring and strengthen social safety nets may be limited by the lack of fiscal headroom or constraints to external financing on market terms. Because the resources from the multilateral 
development banks are also limited, regionally concerted action to mobilise such resources, particularly from the core countries in the region, should contribute greatly to crisis resolution.

In this sense, the so-called New Miyazawa Initiative contributed to crisis resolution. In October 1998, under the leadership of Finance Minister Kiichi Miyazawa, Japan pledged US\$30 billion to support the economic recovery of the crisis-affected countries. Half of the pledged amount was to be dedicated to short-term capital needs during economic restructuring and reform; the rest was earmarked for medium-term and long-term reforms. A commitment to provide a large amount of resources helped stabilise the regional markets and economies, thereby facilitating the recovery process.

\section{Logic of Regional Financial Cooperation in East Asia}

\section{E conomic interdependencein theregion}

Strong regional economic interdependence is the most important rationale for regional financial cooperation. More broadly, regional spillover effects and externalities due to economic interdependence call for regional economic cooperation in various areas, including the establishment of regional common policies toward trade and FDI, harmonisation of standards and regulations, financial sector supervision, intra-regional exchange rate stability, and macroeconomic policy coordination. Though financial cooperation focuses on issues pertinent to financial spheres, it cannot be sustained as a productive tool without broader economic integration at the regional level. ${ }^{7}$

\section{Tradeand FDI integration}

The East Asia region has long enjoyed market-driven integration through trade and FDI, while embracing a multilateral liberalisation framework under the World Trade Organization(WTO) and open regionalism under Asia Pacific Economic Cooperation (APEC) and avoiding discriminatory trade arrangements. The APEC process was successful in encouraging China to pursue trade and FDI liberalisation outside the WTO framework, and inducing other economies in the region to pursue the same objectives. Regional economic integration has been strengthened through FDI. FDI flows to the East Asian economies expanded rapidly in the second half of the 1980s, driven largely by Japanese multinational corporations after the Plaza Accord. FDI flows 
have generated greater intra-industry trade within the region and contributed to deeper economic integration.

The degree of regional integration through trade in East Asia is already high and comparable to levels seen in the North American free trade area (NAFTA) or the European Union (EU). Table 1 summarises intra-regional trade intensity indices for various groupings in the world over the period 1980-2000. The table demonstrates that within groups of East Asia, whether including Japan or not, the indices are larger than those for NAFTA or EU-15. ${ }^{8}$

The ASEAN Free Trade Area (AFTA) used to be the only formal regional trade arrangement in East Asia. ${ }^{9}$ Despite the slow pace of trade liberalisation, AFTA has been in effect among the original five ASEAN members - Indonesia, Malaysia, Singapore, Thailand and the Philippines - since January 2002. Although the exclusion list is long and individual country circumstances vary, most goods traded between these countries are already subject to tariffs of only zero to 5 per cent. Vietnam is to comply with the same tariff standards by 2003, Laos and Myanmar by 2005, and Cambodia by 2007.

Recently, several economies in East Asia have indicated a willingness to embark on regional trade arrangements on a larger scale. Japan concluded a bilateral economic partnership arrangement (EPA) with Singapore, made effective in November 2002. ${ }^{10}$ China and ASEAN are negotiating a free trade arrangement (FTA) to be completed within 10 years. Japan has also proposed an EPA with ASEAN, and is discussing the possibility of similar arrangements with Mexico (under negotiation), Malaysia, the Philippines, South Korea and Thailand (under study). Many other countries in the region have concluded or are negotiating bilateral FTAs with countries inside and outside the region. ${ }^{11}$

Japan's conclusion of a bilateral FTA-EPA with Singapore symbolises a change in its longstanding trade policy of pursuing only multilateral liberalisation. Japan is shifting its trade policy to a three-track approach based on multilateral, regional and bilateral liberalisation. For Japan, regional and bilateral liberalisation is an attempt to achieve deeper integration with trading partners on a formal basis, going beyond reductions in border restrictions, and pursuing investment liberalisation, greater competition in the domestic market, and harmonisation of standards (Box 1). This approach not only is consistent with, but also promotes, the multilateral approach, which remains an important element of Japanese trade policy. 
Table 1 Intra-regional tradeintensity indexa

\begin{tabular}{lrrrrrrrrr}
\hline Region & 1980 & 1985 & 1990 & 1995 & 1996 & 1997 & 1998 & 1999 & 2000 \\
\hline & & & & & & & & & \\
East Asia-15 $^{\mathrm{b}}$ & 2.6 & 2.3 & 2.3 & 2.1 & 2.2 & 2.2 & 2.3 & 2.4 & 2.2 \\
Emerging East Asia-14 $^{\mathrm{c}}$ & 3.0 & 2.9 & 2.8 & 2.3 & 2.4 & 2.4 & 2.6 & 2.5 & 2.4 \\
ASEAN-10 & 5.1 & 6.1 & 4.6 & 3.8 & 3.8 & 3.8 & 4.3 & 4.1 & 3.7 \\
NAFTA & 2.1 & 2.0 & 2.1 & 2.4 & 2.4 & 2.3 & 2.3 & 2.3 & 2.1 \\
European Union-15 & 1.5 & 1.6 & 1.5 & 1.7 & 1.7 & 1.7 & 1.6 & 1.7 & 1.7 \\
MERCOSUR & 6.6 & 4.9 & 9.7 & 13.3 & 14.4 & 14.0 & 14.2 & 14.7 & 15.0 \\
& & & & & & & & & \\
\hline
\end{tabular}

Notes: a The trade intensity index is defined as $\left(\mathrm{X}_{\mathrm{ij}} \mathrm{X}_{\mathrm{i}}.\right) /\left(\mathrm{X}_{. \mathrm{j}} / \mathrm{X}_{\text {... }}\right)$ where $\mathrm{X}_{\mathrm{ij}}$ represents exports from region $i$ to region $j, X_{i}$. represents total exports from region $i, X_{j}$ represents total exports from the world to region $\mathrm{j}$ (or total imports of region $\mathrm{j}$ ), and X.. represents total world trade. In the table, the index is defined only for countries within the same region, so that $i=j$.

b East Asia-15 includes Emerging East Asia-14 and Japan.

c Emerging East Asia-14 includes ASEAN-10, China, Hong Kong, South Korea and Taiwan. Source: Kawai and Urata (2002).

\section{Box 1 Regional tradearrangements in East Asia}

There has recently been a heightened interest in regional trade and investment arrangements in East Asia, with regional trade agreements (RTAs) as well as several bilateral free trade agreements under active discussion. RTAs, if properly designed for trade creation, can be a positive force, especially for smaller economies, for stimulating trade in a global context. There are two main ways in which an RTA can have a positive economic impact in the region. The first is through an enlargement of the market as a whole, with the resulting economies of scale, improved efficiency and greater competitiveness of regional producers. Forming an ASEAN +3 free trade area may be particularly useful for achieving a large-scale regional market. Realising these gains requires inefficient sectors and firms to contract as market pressure develops. The second is through trade and location effects, through the induced improvements in technologies and institutions. Any negative impact from trade diversion to less efficient producers is likely to be offset by the positive impact of technology transfers and modernisation of standards and procedures - as has been the case with the expansion of the ASEAN Free Trade Area to countries such as Vietnam and Cambodia. Growing regional activities can also stimulate demand for intermediate inputs from non-regional sources.

Hence, an RTA could generate significant welfare gains for both the East Asian and global economies if properly designed to expand trade. Gains would also depend on the depth of integration (reductions in tariffs and non-tariff barriers), including investment liberalisation, deregulation of domestic markets to enhance competition, and harmonisation of regulations and standards. 


\section{Financial integration}

Financial integration has also proceeded as a result of the increased liberalisation of the financial system and the capital account. Commercial banks operating throughout the region have contributed to a closely connected banking sector within East Asia. Opening of securities markets, particularly equity markets, has attracted foreign portfolio capital flows. As a result, there have been positive correlations of stock price movements within the region. Greater commercial bank lending and portfolio flows have linked the economies in the region financially.

\section{Macroeconomi cinterdependence}

Macroeconomic interdependence within the region has recently become stronger, as evidenced by a simultaneous contraction of economic activity throughout East Asia in 1998 and a simultaneous expansion in 1999-2000. Though the regional economies may have been affected by some common factors such as US economic and information technology stock price cycles, much of the recent, synchronised economic activities in the region can be attributed to strong macroeconomic interdependence.

Indeed, earlier studies by Eichengreen and Bayoumi (1999) found that, in terms of supply shocks, some East Asian nations were just as closely connected with one another as European countries were. In terms of demand shocks, ASEAN countries were also well connected. ${ }^{12}$ The Kobe Research Project Study on Regional Financial Cooperation and Surveillance, conducted by the Japanese team (IIMA 2002), also found increasing macroeconomic interdependence in East Asia in the 1990s, in terms of movements of real output and shocks to real investment. ${ }^{13}$

\section{Information sharing and regimesetting for regional financial cooperation}

The presence of deepening economic interdependence in East Asia suggests that there is a case for economic policy cooperation at the regional level. The pace and extent of crisis contagion observed in the region in the second half of 1997 also suggest that regionally coordinated action to contain contagion is logical. An efficient cooperative framework for regional financial management can be useful in coping with serious currency crises and contagion. In a region where economic fluctuations, policies and shocks are transmitted across countries, positive outcomes can be expected from cooperative financial policies and frameworks. In this context, three types of financial cooperation could be pursued in the region: policy optimisation, regime setting or information sharing. ${ }^{14}$ 
Policy optimisation is a joint maximisation of a weighted sum of economic welfare of the countries concerned. It often takes the form of policy exchanges where one country pursues monetary policy expansion while another pursues monetary policy contraction. This type of policy coordination was a hot topic in academic and policy circles from the mid-1980s to the early 1990s for the G-7 countries. In particular, the United States, Japan and Germany took coordinated action to induce US dollar depreciation in 1985 and, when the dollar declined too far, to preventits fall in $1987 .{ }^{15}$ The European economies have been coordinating their monetary policies at least since 1979 under the European Monetary System (EMS). While one may question whether the approach taken by these industrialised countries can be a useful guide to emerging market economies, coordinated action in macroeconomic policy could be productive under the right circumstances.

Not all East Asian economies have the capacity to carry out credible national economic policies or regionally coordinated policies. For example, Indonesia continues to suffer from the fallout of the crisis, and setting the right macroeconomic framework is proving to be a challenge. The primary objective of economic policies of less developed countries such as Cambodia, Laos, Myanmar and Vietnam is to accelerate economic development and poverty reduction by promoting industrialisation, structural changes, and human resource development. It may be difficult for these economies to follow internationally agreed economic policies. Nonetheless, regional financial cooperation would eventually require coordinated policy action on the part of many economies in the region.

Regime setting is a joint exercise to agree on a set of rules within which individual countries can conduct independent policymaking to pursue their own economic interests. This type of policy cooperation includes agreements on such issues as regional trade and FDI arrangements, regional exchange rate regimes, regional financing arrangements, other regional frameworks for action at the time of a crisis, and initiatives for regional bond market development. An example is a joint setting of exchange rate policies for intra-regional exchange rate stabilisation, which can prevent competitive depreciation at the regional level. Another example is the creation of a regional financing facility, which can contain regional currency attacks and contagion quickly, supplement IMF roles and resources, and economise on resources through reserve pooling at the regional level. Yet another example is an initiative for regional bond market development, which encourages the economies in the region to make concerted efforts to develop national bond markets as well as regional infrastructure, including clearance, settlements, and rating agencies. 
A third profitable approach for interdependent economies in the region would be to establish a cooperative framework that encourages frequent information sharing. Regional policy dialogue and surveillance mechanisms facilitate greater information sharing, closer monitoring of regional economic conditions and short-term capital flows, and peer pressure to develop better policies. These improve each country's understanding of its peers' economic performance, macroeconomic and structural issues, policy objectives, and policy choices. A cooperative framework enhances the economic welfare of the countries concerned because it enables each country to use more accurate information about other countries in its own policymaking.

Though policy optimisation is an unrealistic option at this stage, there is scope for the East Asian economies to pursue at least two types of policy cooperation: regime setting and information sharing. These would probably be the most productive mechanisms for cooperation at present. Given the already strong economic interdependence among the region's economies, they will benefit by establishing a framework for exchange rate stabilisation and then gradually moving toward collective efforts in monetary-fiscal policy coordination based on policy exchanges.

\section{Challenges for closer financial cooperation in East Asia}

Both advocates and sceptics of East Asian financial cooperation have argued that the regional economies face several challenges for closer cooperation. ${ }^{16}$

The most serious challenge reflects the fact that the regional economies are diverse and heterogeneous in terms of per capita incomes, stage of economic development, institutional capacity, and economic systems and structures. Such diversity and heterogeneity create obvious difficulties for any attempt to agree on coordinated policies. In order for the economies to take joint action at the regional level, there must be substantial economic convergence.

The second challenge is how to create conditions for political leadership to emerge. Currently there is no strong political leadership in the region, due to differences in political systems and the lack of full mutual trust. In East Asia no single economic power plays a dominant role like that of the United States in the western hemisphere, nor is there any bipolar relationship like the Franco-German alliance in Western Europe. Japan is currently suffering economic stagnation, and China, while rapidly emerging as an economic power, has yet to achieve transition from a planned to a market economy and from one-party rule to democracy. It will take time for any bipolar alliance to emerge in East Asia. 
The third challenge is how to go beyond the so-called 'consensus' culture. Cooperation in East Asia has been characterised by consensus decision-making and a presumption of nonintervention in domestic affairs. The emphasis on consensus, non-interference and good manners has nurtured a shallow form of regional financial cooperation so far. For much deeper policy cooperation, the economies in the region must be ready to accept constructive comments and criticisms on their policymaking and, hence, a certain degree of friendly intrusion from their peers.

The fourth challenge is how to create sufficient incentives for regional financial cooperation given that the region is economically open to the rest of the world. While intra-regional trade and investment interdependence are rising, East Asia is not self-contained in terms of trade and financial flows. The region needs North America and Europe as destinations for its export products. The region also allocates a substantial amount of financial wealth in US dollar denominated assets. Essentially, the challenge is how to make East Asian regionalism attractive when it is embedded in the larger global system.

The difficulties underlying these challenges may have prevented the economies in East Asia from pursuing serious financial (as well as broader economic) cooperation so far. However, the East Asian crisis has revealed the importance of regional financial cooperation, possibly by raising the perceived pay-offs to cooperation. Despite heterogeneity and differences in political systems among the economies in the region, countries have increasingly come to realise the strength of the economic logic for further cooperation. As the region makes progress on economic and financial cooperation, the resulting institution building would provide further impetus for more ambitious cooperation.

\section{East Asian Initiatives for Regional Financial Cooperation}

Initiatives to strengthen regional financial cooperation in East Asia have so far fallen into three broad areas: information sharing, policy dialogue and economic surveillance; regional financing arrangements; and coordination of exchange rate policies.

\section{Regional policydialogueand surveillancemechanisms}

There are several mechanisms for regional information sharing, policy dialogue, and economic surveillance. Three major initiatives are the ASEAN Surveillance Process, the ASEAN+3 Framework, and the Manila Framework Group (MFG). Other initiatives include SEANZA 
Pacific Economic Papers

(South East Asia, New Zealand, Australia), SEACEN (South East Asian Central Banks), and EMEAP (Executives Meeting of East Asia-Pacific Central Banks) for central banks, APEC and ASEM (Asia-Europe Meeting) for trans-regional policy dialogue, and smaller groups (see Table 2).

Table 2 Regional forums for finance ministries and central banks

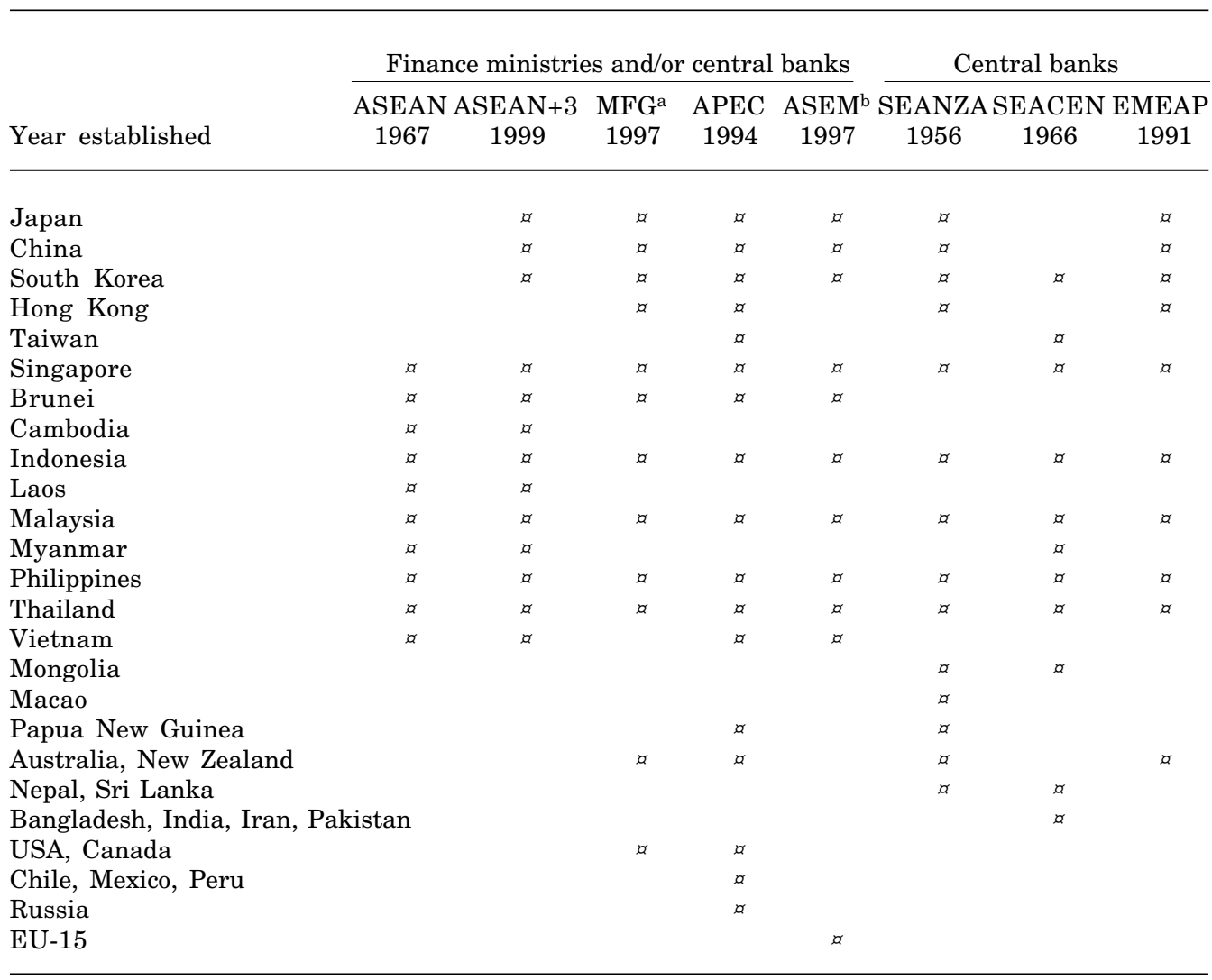

Notes: $\quad$ APEC = Asia-Pacific Economic Cooperation; ASEAN = Association of Southeast Asian Nations; EMEAP = Executives Meeting of East Asia-Pacific Central Banks; MFG = Manila Framework Group; SEACEN = South East Asian Central Banks; SEANZA = South East Asia, New Zealand, Australia.

a Includes the International Monetary Fund, the World Bank, the Asian Development Bank and the Bank for International Settlements.

b Includes the European Commission. 


\section{ASEAN SurveillanceProcess}

While the economic goal of ASEAN has been the promotion of trade and investment flows in the region, the recent success of European countries to complete economic and monetary integration has encouraged ASEAN to think that it might productively pursue similar goals.

The ASEAN Surveillance Process was established in October 1998 when the ASEAN finance ministers signed a 'terms of understanding' for regional cooperation. The objective of the process was to strengthen policy dialogue and policymaking capacity in monetary, fiscal and financial areas through information exchanges, peer reviews and recommendations for action at the regional and national levels. For this purpose, the ASEAN Surveillance Process is designed to monitor macroeconomic developments, capital flows, exchange rates, and structural and social policies, and to include provisions for capacity building, institutional strengthening, and information sharing. The ASEAN finance ministers meet twice a year for policy coordination under this process.

The ASEAN Surveillance Coordinating Unit (ASCU), established at the ASEAN Secretariat in Jakarta, prepares an ASEAN Surveillance Report. Using the same data supplied to the IMF in conjunction with its Article IV consultations and program negotiations, the ASCU performs an analysis of the latest economic and financial conditions in ASEAN while taking into account global developments that affect the regional economies. The exercise has recently been strengthened by the establishment of national surveillance units in several ASEAN countries (Cambodia, Indonesia, Laos, the Philippines, Thailand, and Vietnam), which produce drafts of country chapters. The Asian Development Bank (ADB) supports this process by preparing an ASEAN Economic Outlook and special issue studies, as well as providing technical assistance. ${ }^{17}$ The ASEAN Surveillance Report is considered and finalised by the ASEAN finance and central bank deputies before it is submitted for discussion by the ASEAN finance ministers during their peer review session.

The ASEAN Surveillance Process is the first concrete attempt by a group of developing countries to establish mechanisms for information sharing, policy dialogue, and individual and collective responses to events that could adversely affect subregional economies. It has two components. The first is a monitoring mechanism that allows early detection of any irregular movement in key economic and financial variables; the second is a peer review mechanism that induces appropriate policy responses to issues emerging from the monitoring exercise. 


\section{ASEAN +3 E conomic Review and Policy DialogueProcess}

The Asian financial crisis in 1997 highlighted the need to strengthen regional cooperation and urged the heads of state or government of the ASEAN+3 group, consisting of ASEAN-10 and China, Japan and South Korea, to meet for the first time in December 1997 to discuss regional peace, stability and prosperity. To promote regional financial cooperation in particular, the first ASEAN+3 Finance Ministers Meeting was held in April 1999 on the sidelines of the ADB annual meeting in Manila. The ASEAN+3 leaders recognised the need for 'enhancing self-help and support mechanisms in East Asia through the ASEAN+3 Framework' in November 1999. ${ }^{18}$ Following this recognition, the ASEAN+3 Economic Review and Policy Dialogue (ERPD) was introduced in May 2000. Under this process, the ASEAN+3 finance ministers have met annually, in principle to exchange information and discuss policy issues.

The purpose of the ASEAN+3 ERPD process is to strengthen policy dialogue, coordination and collaboration on the financial, monetary and fiscal issues of common interest. Its major focus is on issues related to macroeconomic risk management, better corporate governance, monitoring of regional capital flows, strengthening of the banking and financial systems, reform of the international financial architecture, and enhancement of self-help and support mechanisms in East Asia. Steps have been taken for cooperation in monitoring short-term capital flows and developing a regional early warning system to assess regional financial vulnerabilities, with a view to preventing financial crises in the future.

The first peer review meeting under the ASEAN+3 ERPD Process was held in May 2000 on the sidelines of the ADB annual meeting. Like the ASEAN Surveillance Process, the ASEAN+3 ERPD Process has not yet been as effective as it should be. There is no secretariat to support the logistics of the process, and there is no organisational structure to provide substantive inputs into the process, except that the ADB provides some data on developing member economies. Recognising the importance of enhanced monitoring of economic conditions in the region, the ASEAN+3 finance ministers agreed at their fourth meeting, in Honolulu in May 2001 , to establish a study group to discuss feasible mechanisms for economic reviews and policy dialogue. ${ }^{19}$

\section{Manila FrameworkGroup}

Inspired by the success of the Tokyo meeting to create a much-needed financial support package for Thailand in August 1997, Japan, with support from South Korea and the ASEAN countries that participated in the Thai package, proposed to establish an Asian Monetary Fund (AMF) 
to supplement IMF resources for crisis prevention and resolution. The United States and the IMF opposed this proposition on grounds of moral hazard and duplication. They argued that an East Asian country hit by a currency crisis would bypass the tough conditionality of the IMF and receive easy money from the $\mathrm{AMF}$, thereby creating potential for moral hazard; and that an $\mathrm{AMF}$ would be redundant in the presence of an effective global crisis manager, the IMF.

The idea was dropped, but in November 1997 the East Asian economies, together with the United States, Canada, Australia and New Zealand, agreed to establish the MFG. ${ }^{20}$ Its objective is to develop a concerted framework for regional financial cooperation in order to restore and enhance the prospects for financial stability in the region. ${ }^{21}$ Its initiatives include the establishment of a new mechanism for regional surveillance to complement global surveillance by the IMF; enhancement of economic and technical cooperation, particularly in strengthening domestic financial systems and regulatory capacities; strengthening the IMF's capacity to respond to financial crises; and development of a cooperative financing arrangement for the region to complement IMF resources.

One notable feature of the MFG is its establishment of a new mechanism for regional surveillance. This mechanism would provide a basis for an intensive and high-level process of surveillance and dialogue among participating finance ministries and central banks with support from the IMF, World Bank, ADB and Bank for International Settlements (BIS). The MFG is a process for finance and central bank deputies. By March 2003, the group had met 10 times.

As indicated by the IMF's characterisation of the MFG as the 'preeminent forum for Asian regional surveillance and peer pressure', ${ }^{22}$ the MFG's strength lies in its capacity to carry out more effective policy dialogue than any other regional forum. It has no permanent secretariat or funding of its own.

\section{Central bank forums}

Asian central banks also have their own policy dialogue processes, including SEANZA, SEACEN and EMEAP.

The SEANZA Group grew out of a 1956 meeting of central bank governors from the AsiaOceanic region and is one of the oldest and largest regional forums in terms of membership. It is a forum for exchanges of information on issues and problems of common interest among central banks and for providing training courses for central bank staff. 
SEACEN was established in February 1966, initially as a training and research organisation. It has evolved into a more substantive forum for discussion of central banking issues. Membership includes the major Southeast Asian economies as well as South Korea and Taiwan. It runs a training centre in Kuala Lumpur.

EMEAP was organised in February 1991 with the leadership of the Bank of Japan and the Reserve Bank of Australia. Its major objectives include enhanced regional surveillance, exchanges of information and views, and the promotion of financial market development. Its activities include annual meetings of EMEAP central bank governors, semi-annual meetings of the deputy governors, and three working groups concerned with bank supervision, financial markets, and payments and settlement systems. ${ }^{23}$ Like the MFG, EMEAP has no secretariat; instead, the responsibility for organisational matters, along with the meetings themselves, is rotated among the participating central banks.

Since late 1997, central banks of ASEAN members have started to meet for policy dialogue as the ASEAN Central Bank Forum.

\section{APEC and ASEM}

The region has also developed trans-regional arrangements with the Americas (APEC) and the European Union (ASEM).

The objective of APEC has long been trade and investment liberalisation and facilitation among the Asia Pacific countries, including the United States and Canada. The APEC Finance Ministers Meeting was established in March 1994 as a main forum for the exchange of views and information on macroeconomic conditions, capital flows, and financial market development. The IMF, the World Bank and the ADB help to prepare papers on relevant issues. A distinctive feature of APEC is that ministers invite representatives from the private sector-Asian Bankers Association Council, APEC Financiers Group, and Pacific Economic Cooperation Council-to briefly report on their work and discuss issues.

At the first Asia-Europe Meeting in March 1996, the heads of states of Asian and EU countries initiated a process for strengthening partnership between Asia and the EU. The ASEM Finance Ministers Meeting was established in September 1997. By March 2003, three meetings had been held. From 2002, the meetings began to be held annually. The European Commission is a regular member and the IMF, European Central Bank and ADB contribute to discussions. One hallmark activity was the Kobe Research Project, which was designed to promote regional 
monetary cooperation in East Asia, by taking into account the lessons learned from the European integration experience.

\section{Smaller-scal eregional groups}

There are several smaller-scale meetings for information exchange in the region, including the Four Markets Meeting (Australia, Hong Kong, Japan and Singapore, established in May 1992), the Six Markets Meeting (China, the United States and the Four Markets Meeting members, starting in March 1997), and the Trilateral Finance Ministers Meeting (China, South Korea and Japan, starting in September 2000). These groups discuss such regional issues as macroeconomic conditions, capital flows, foreign exchange markets, and financial market developments. By March 2003, the Four Markets Meetings had been held 16 times and the Six Markets Meetings twice. They are attended by finance and central bank deputies. A second Trilateral Finance Ministers Meeting was held in May 2002.

\section{Regional financingfacilities}

The IMF has a limited role as an international lender of last resort, so a regional financing facility can play a useful role in crisis prevention and management. With good policies and disciplines, it can do this through timely and adequate provision of international liquidity at times of currency attack, contagion and crisis. Under the CMI, the longstanding ASEAN Swap Arrangement (ASA) has been strengthened and bilateral swap arrangements for the ASEAN+3 members, including China, Japan and South Korea, have been introduced.

\section{ASEAN Swap Arrangement}

In August 1977 the original five ASEAN central banks and monetary authorities - Indonesia, Malaysia, the Philippines, Singapore, and Thailand-signed the first memorandum of understanding on the ASA. The total facility was US $\$ 100$ million, with each member contributing US $\$ 20$ million. In 1978 , the total was increased to US\$200 million, with each member contributing US $\$ 40$ million. The objective was to provide immediate, short-term swap facilities to any member facing a temporary liquidity shortage or a balance of payments problem. ${ }^{24}$

However, the Asian financial crisis highlighted the importance for the facility to be able to respond more effectively to the needs of its members in a world of increased financial globalisation. At the ASEAN Finance Ministers Meeting in March 2000, it was decided to extend 
membership to include Brunei, Cambodia, Laos, Myanmar and Vietnam. In November 2000, 10 ASEAN members signed a new memorandum of understanding to expand the ASA membership to all 10 ASEAN central banks and monetary authorities and to enlarge the size of the swap facility from US $\$ 200$ million to US $\$ 1$ billion. This reflected the CMI objectives. The founding ASEAN members and Brunei now contribute US $\$ 150$ million each, while the other members contribute smaller amounts (Vietnam US $\$ 60$ million, Myanmar US\$20 million, Cambodia US $\$ 15$ million, and Laos US $\$ 5$ million). The ASA allows member central banks to swap their domestic currencies with major international currencies, such as the US dollar, Japanese yen and euro, for an amount of up to twice their commitment amount under the facility, and for a period of up to six months. ${ }^{25}$

\section{Bilateral swap arrangements under theChiang Mai I nitiative}

The finance ministers of ASEAN+3 who met in Chiang Mai in May 2000 also agreed to establish a regional network of bilateral swap arrangements (BSAs) under the CMI. In addition to expanding the existing ASA, the CMI is designed to create a new network of bilateral swap and repurchase arrangements among Japan, China and South Korea as well as between each of these and any one of the ASEAN countries (see Figure 1). ${ }^{26}$ By the end of March 2003, 12 BSAs had been concluded in line with the main principles, reaching a total of US $\$ 39$ billion (see Table 3 ). ${ }^{27}$ Negotiations for two BSAs are under way. ${ }^{28}$

At Chiang Mai, the ASEAN+3 countries agreed on the basic framework and main principles of bilateral swap arrangements, including linkages to the IMF, maturity and interest. For example, countries can borrow liquidity collateralised by domestic currencies with government guarantees, rather than offering US treasury bonds as collateral. The swap will be for 90 days, renewable up to seven times, at an interest rate equivalent to the LIBOR plus 150 basis points for the first drawing and first renewal. Thereafter, the premium rises by 50 basis points every two renewals, subject to a maximum of 300 basis points. Negotiations on the swap arrangements are to be concluded bilaterally, based on the agreed main principles.

Members requesting liquidity support under the CMI can immediately obtain short-term financial assistance for the first 10 per cent of the BSA facility. The remaining 90 per cent is provided to the requesting member under an IMF program or an activated contingent credit line. This linkage of disbursements to IMF conditionality is designed to address the concern that balance of payments difficulties may be due to fundamental problems and that the potential 


\section{Figure 1 Network of bilateral swap arrangements under the Chiang} Mai Initiative

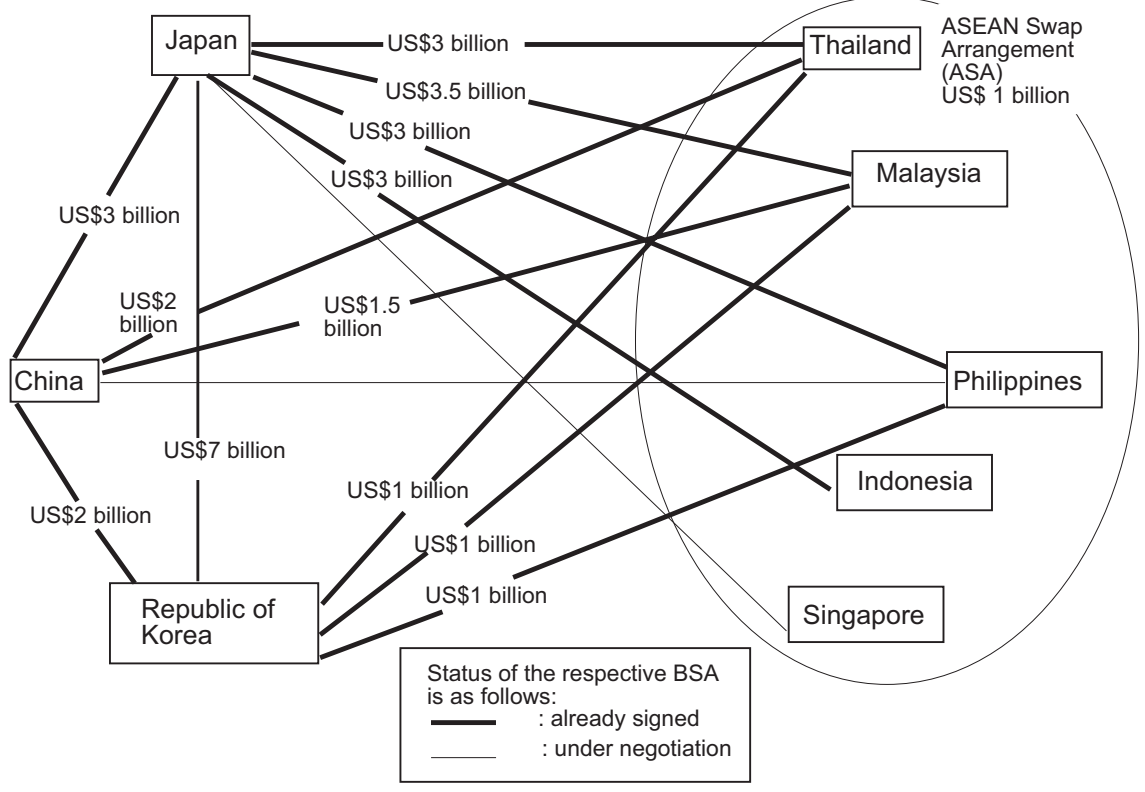

Note: 1 The BSAs for Japan-Korea and Japan-Malaysia include the BSAs under the New Miyazawa Initiative (US\$5 billion and US $\$ 2.5$ billion, respectively).

2 The BSAs for Japan-China, China-South Korea, South Korea-Malaysia, and South KoreaPhilippines are local currency swap arrangements.

moral hazard problem could be non-negligible in the absence of an effective adjustment program. $^{29}$

\section{MFG cooperativefinancingarrangements}

One of the MFG's objectives is the development of a cooperative financing arrangement (CFA) for the region that would supplement resources from the IMF and other international financial institutions. Under this arrangement CFA participants could provide supplemental financial resources for IMF-supported programs, in consultation with the IMF and on a case-by-case basis. In exceptional circumstances, such support could augment a country's foreign exchange reserves after it had used resources made available by the IMF. ${ }^{30}$ 
Table 3 Progress on BSAs under the Chiang Mai I nitiative (as of end-March 2003)

\begin{tabular}{|c|c|c|c|}
\hline $\begin{array}{l}\text { Bilateral swap arrange- } \\
\text { ments (BSAs) }\end{array}$ & Currencies & Conclusion date & $\begin{array}{l}\text { Size(US\$ } \\
\text { billion) }\end{array}$ \\
\hline Japan-South Korea & USD-won & 4 July 2001 & $7.0^{\mathrm{a}}(1-\mathrm{way})$ \\
\hline Japan-Thailand & USD-baht & 30 July 2001 & 3.0 (1-way) \\
\hline Japan-Philippines & USD-peso & 27 August 2001 & 3.0 (1-way) \\
\hline Japan-Malaysia & USD-ringgit & 5 October 2001 & $3.5^{\mathrm{b}}$ (1-way) \\
\hline China-Thailand & USD-baht & 6 December 2001 & 2.0 (1-way) \\
\hline Japan-China & Yen-renminbi & 28 March 2002 & $3.0^{\mathrm{c}}$ (2-way) \\
\hline China-South Korea & Renminbi-won & 24 June 2002 & $2.0^{\mathrm{c}}$ (2-way) \\
\hline South Korea-Thailand & USD-won or USD-baht & 25 June 2002 & 1.0 (2-way) \\
\hline South Korea-Malaysia & Won-ringgit & 26 July 2002 & $1.0^{\mathrm{c}}$ (2-way) \\
\hline South Korea-Philippines & Won-peso & 9 August 2002 & $1.0^{c}$ (2-way) \\
\hline China-Malaysia & USD-ringgit & 9 October 2002 & 1.5 (1-way) \\
\hline Japan-Indonesia & USD-rupiah & 17 February 2003 & 3.0 (1-way) \\
\hline Japan-Singapore & Under negotiation & & \\
\hline China-Philippines & Under negotiation & & \\
\hline China-Indonesia & To be negotiated & & \\
\hline South Korea-Indonesia & To be negotiated & & \\
\hline
\end{tabular}

Notes: a The amount includes US $\$ 5$ billion committed under the New Miyazawa Initiative.

b The amount includes US $\$ 2.5$ billion committed under the New Miyazawa Initiative.

c US\$ equivalents.

\section{Regional exchangeratearrangement}

Not much progress has been made in the area of exchange rate coordination or stabilisation in the region, despite the desirability of stable exchange rates in East Asia. One of the reasons for the lack of progress could be the fact that there is no international rule or best practice with regard to exchange rate regimes. The popular 'two-corner solution' view focuses exclusively on crisis prevention. However, countries can rightly pursue growth, trade, investment promotion and other objectives through exchange rate policy. As Frankel (1999) has argued, the optimal exchange rate regime depends on the circumstances of a particular country and time, and there is no single regime to fit all emerging market economies.

For the emerging East Asian economies that depend heavily on trade and investment, exchange rate stability is desirable for the promotion of trade and investment and economic development. In addition, intra-regional exchange rate stability is a public good for the East Asian economies that have increasingly integrated with one another. In the pre-crisis period, de 
facto US dollar pegged exchange rate regimes ensured extra-regional as well as intra-regional exchange rate stability on an informal basis. However, a US dollar based regime was susceptible to fluctuations in effective exchange rates when the dollar-yen rate became volatile in 1995 and 1998.

When the currency crisis led to a collapse of the then prevailing defacto US dollar based exchange rate regimes in crisis-hit economies, East Asian countries moved to more flexible exchange rate regimes. In the post-crisis period, they began to show a diversity of exchange rate arrangements. Some economies reverted to US dollar based regimes - notably Malaysia, which restored a formal US dollar peg. Indonesia and the Philippines increased exchange rate flexibility; South Korea and Thailand appear to have shifted to a currency basket type arrangement (see Kawai 2002).

For emerging market economies in East Asia, a pure float is not desirable because of a potential for excessive volatility and misalignment. Nor is a hard peg desirable except in small open economies like Hong Kong and Brunei. However, the region is beginning to take action to coordinate exchange rate policies - for example, through the ASEAN Task Force on ASEAN Currency and Exchange Rate Mechanism, established in March 2001.

\section{Moving forward}

\section{Moreeffectiveregional surveillance}

There are already several forums for information sharing, policy dialogue, and economic surveillance in the region, ${ }^{31}$ but none is effective at this point. To be effective, the surveillance process needs to put more emphasis on technical discussions and create an environment for serious policy discussions by taking an appropriate balance between consensus, noninterference and good manners on one hand and strong peer pressure on the other. The surveillance process must encourage frank discussions on the technical substance without being abrasive and confrontational.

This process is particularly important as the CMI may develop into an important source of financial facilities and the ASEAN+3 ERPD Process will have to be strengthened beyond the peer review process. While this may imply a challenge in the tradition of a presumption of noninterference in domestic affairs, ASEAN +3 policymakers need to appreciate the necessity of constructive engagement. One feasible option in this direction would be to set up a technically competent third party unit. Its role would be to assist the ERPD process by providing high-quality 
and in-depth economic reviews and assessments, timely identification of emerging issues and vulnerabilities affecting the region, and effective policy advice.

It is important to provide sufficient incentives for countries in the region to participate in the economic surveillance process. Each economy in the region must be convinced that going through the surveillance process focusing on its own economy would be to its benefit because it sends positive signs to the international community and investors and helps establish its own credibility and reputation. In addition, potential recipients of regional liquidity can benefit from participation in the surveillance process through implementation of liquidity support at times of a crisis or contagion.

\section{Regi onal bond market development}

The region needs to develop bond markets as an alternative source of financing in view of the heavy dependence on bank-based financing. In particular, the development of market infrastructure for local currency-denominated bonds is desirable to reduce the double mismatch problem - that is, the mismatch of maturity and currency, which was at the heart of the East Asian currency crisis. The basic idea is to mobilise the region's vast pool of savings to be intermediated directly to regional long-term investment, without going through financial intermediaries outside the region. Regional financial intermediation through bond markets would diversify the modes of financing in the region and reduce the double mismatch.

Once such markets become sufficiently deep and liquid, foreign investors would also be induced to purchase Asian currency-denominated bonds, thereby enabling the region to overcome the so-called 'original sin' problem. ${ }^{32}$ This effort should begin first at the country level with sovereign bonds and then private bonds, and second at the regional level to encourage the development of regional bond markets. At the country level, a useful step would be to allow nonresidents - such as multinational corporations - to issue local currency-denominated bonds to satisfy their local financing needs. At the regional level, the countries must make concerted efforts and coordinate on clearance and settlement, information disclosure, accounting and auditing standards, and rating agencies. In addition, the region may embark on the issuance of common currency-denominated bonds, such as ACU bonds (see below).

\section{Regional reservepooling}

The CMI BSAs are to be reviewed in 2004. At that time, East Asian countries may decide to amend the arrangement, to make it permanent, or even to begin the process to transform it into 
a more formal institution like a regional monetary fund. One option is for each monetary authority of the ASEAN+3 group to set aside a modest share of its foreign exchange reserves and place the funds in a common pool with the other 12 central banks. The funds could be drawn to support countries that are affected by currency speculation, contagion or crisis. Such regional reserve pooling makes sense because Japan, China and others collectively have abundant foreign exchange reserves and could economise on their use through the establishment of a common pool.

Several mechanisms have been proposed for such reserve pooling schemes. They include a Framework for Regional Monetary Stability (IIMA 2000), an East Asian Fund (Ito et al. 1999) and two versions of a regional financing arrangement (Yoshitomi and Shirai 2000; Chaipravat 2001). To go beyond the CMI and operate such a formal institution for foreign exchange reserve pooling, the region must address the earlier concern that an AMF that could lend too generously with too little conditionality might create moral hazard for the government at the receiving end as well as for investors with stakes in the countries in question. To minimise moral hazard, it is essential to strengthen the surveillance process, improve the capacity to formulate appropriate adjustment policy in the event of liquidity provision and, to the extent necessary, enforce effective private sector involvement.

\section{Regional common unit of account}

It is time to introduce a regional common unit of account in East Asia. One way to do this is to construct a basket of regional currencies that include 13 currencies for ASEAN+3-the Japanese yen, the Chinese renminbi, the South Korean won, the Singapore dollar, the Malaysian ringgit, the Thai baht and so forth. Just like the European currency unit (ECU) under the EMS (197998), the weights of the regional currencies would reflect the relative importance of the countries in the region. Such a currency basket could be called the Asian currency unit (ACU). The ACU could be used to denominate economic transactions (trade and capital flows) and asset stocks (foreign exchange reserves and cross-border bonds) and to measure the degree of each currency's exchange rate deviation from the regional average.

When the regional emerging market economies adopt a G-3 currency basket arrangement based on the Japanese yen, the US dollar and the euro, the ACU will also become a defacto basket of the G-3 currencies. This will create a zone of currency stability within East Asia. Even without a G-3 currency basket arrangement, creation of an ACU would be a significant step toward closer financial cooperation in the region. 


\section{Exchangeratecoordination}

There have been several proposals for developing a cooperative framework for regional exchange rate stability.

First, McKinnon (2001) and Mundell (2001) have suggested using the US dollar standard to achieve regional exchange rate stability. The advantage is that the emerging East Asian economies can use simply the most dominant international currency; the US dollar standard is simple and involves no additional cost in ensuring exchange rate stability extra- and intraregionally. However, it would result in undesirable fluctuations in effective exchange rates in the face of volatile movements in yen-dollar exchange rates.

Second, Williamson (1999a,b), Kawai and Takagi (2000), French and Japanese Staff (2001), Ito (2001), Kawai (2001, 2002) and Ogawa and Ito (2002) have suggested a G-3 currency basket system in which a currency's central rate is linked to a basket of major currencies - the US dollar, the Japanese yen, and the euro - rather than to the US dollar alone. Initially, the tightness of the link and the currency weights could be left to each authority's choice. As the authorities realised the importance of intra-regional exchange rate stability, there could be closer coordination on the choice. The virtue of this system is that it would prevent excessive fluctuations in effective exchange rates in the face of volatile yen-dollar or euro-dollar rate movements, while allowing the currencies of East Asian countries some flexibility to move within a certain range. It is also consistent with inflation targeting if the latter is defined appropriately (Box 2).

Finally, there is a view that a basket system based on the G-3 currencies is unfair because it gives the Japanese yen special advantages by treating it asymmetrically vis-à-vis other East Asian currencies. Wang (2002) suggests that, in the spirit of regional cooperation, a more symmetric approach, such as the joint formation of a common currency union like the EMS or the euro area, is more appropriate.

Such an approach makes sense but only in the long run. In the long run, the region may develop a common currency arrangement, like the euro regime. However, it cannot be expected to develop in the very near future because there is no convergence of macroeconomic conditions and economic structures and systems. A monetary union would require relatively closely coordinated economic policies and similar market infrastructures to be in place long before it was implemented. A more realistic approach would be for emerging East Asian countries to shift to a currency basket system now, thereby minimising the impact of yen-dollar exchange rate volatility on their economies. They could then start to build institutions, strive for deeper economic interdependence, and achieve economic convergence for future monetary integration. 


\section{Box 2 Recommending a G-3 currency basket system for emerging E ast Asia}

The yen-US dollar exchange rate has been fluctuating, reflecting market demand and supply. China, South Korea and a few other economies in East Asia often express their concerns over the weakness of the yen when the yen happens to depreciate, but do not complain when the yen appreciates. Given that yen-dollar volatility is expected to continue, emerging market economies in East Asia are encouraged to adopt exchange rate regimes that can cope with such volatility.

A reasonable move may be a shift to a free float with inflation targeting. But many economies in the region, including those that have already shifted to floating rate regimes such as South Korea and Thailand, do not want to see wild fluctuations of their exchange rates. They prefer a certain degree of exchange rate stability due to their 'fear of floating'. This fear is understandable. For outward-oriented development and growth, relatively stable exchange rates are desirable.

The emerging market economies in the region are better off by moving to a de facto managed float, with the central rate linked to a basket of the world's major currencies: the US dollar, the yen, and the euro. This will allow the effective exchange rate to remain relatively stable in the face of volatile yen-dollar or euro-dollar exchange rates. A G-3 currency basket system preserves both flexibility and stability, promoting trade, FDI and economic development. Inflation targeting with a band can be consistent with the basket system if the target inflation rate is a weighted average of the G-3 inflation rates, with the inflation weights set equal to the currency basket weights.

(Kawai and Takagi 2000).

\section{Concluding Remarks}

Regional financial cooperation in East Asia is still in its infancy. Institutions and initiatives are not sufficiently developed for significant regional economic integration. Nonetheless, some important steps have been taken. The CMI is dealing with the issues of regional liquidity support, and several forums have been created for information sharing, policy dialogue and economic surveillance among the financial authorities. As yet, there have been no visible steps towards exchange rate stabilisation or for macroeconomic policy coordination. East Asian countries maintain open regionalism in the global system governed by the WTO, the IMF and the World Bank, while keeping close dialogues with the Americas and the European Union.

Further regional cooperation will require freer movements of goods, services and labour; convergence of per capita incomes, economic structures and systems, and institutions; and creation of a sound financial system and development of deeper capital markets. A stronger surveillance process is essential not only for better information sharing and policy dialogue, but also for in-depth understanding of the region's economies, more effective policymaking to avoid crises, and better responses to a crisis once it breaks out. The CMI could lead to the creation of a more formal, reserve pooling institution; then minimising the moral hazard problem would 


\section{Pacific Economic Papers}

be an important challenge for the region. A framework for exchange rate and monetary policy coordination will have to be developed.

Regional financial cooperation in East Asia is unlikely to be of a North American type, where a US-centred, asymmetric approach has driven regional joint initiatives - mainly in trade and investment liberalisation. For East Asia, a European-style, symmetric approach would be more realistic. Japan and China are big powers in Asia, but neither is dominant. Regional financial cooperation can be beneficial to all economies given the potential for dynamic economic growth and the availability of abundant financial resources. Japan, China and South Korea and ASEAN must work jointly towards further financial cooperation in the region. Strong political will and a vision for regional integration will be required for such endeavours. 


\section{Notes}

This is a revised version of the paper presented to the Seminar on 'Regional Economic, Financial and Monetary Co-operation: The European and Asian Experiences,' organised by the European Central Bank in Frankfurt am Main, 15-16 April 2002. The views expressed in this paper are those of the authors and do not necessarily represent the views of the Japanese government.

1 See Eichengreen (1999) and Kenen (2001) for a discussion of reforms of the international financial architecture.

2 Similar approaches might be needed for private debt instruments as well, because of the surge in private-to-private capital flows - as was the case in East Asia.

The FSAP is intended to strengthen the monitoring and assessment of financial systems in view of the fact that financial sector weaknesses have played an important role in damaging a country's overall economic health.

See also Bird and Rajan (2002).

Some countries generate more contagion effects than do other countries. Allocating resources to only one country in the midst of a regional crisis might not be very effective, because other neighbouring countries may suffer contagion. Moreover, preventing and containing crises in the countries that generate more spillover is relatively more effective for controlling regional and global shocks. See Kawai et al. (2001).

For example, see Feldstein (1998).

$7 \quad$ Sakakibara and Yamakawa (2001) provide a comprehensive treatment of these issues.

8 The trade intensity index measures closeness between regions (in the case of Table 1, closeness among economies within a region) relative to the region's weight in the global economy. It is interesting to note that MERCOSUR has a trade intensity index that is higher than any other regional grouping.

$9 \quad$ AFTA is complemented by the ASEAN Industrial Complementation Scheme for investment liberalisation. This scheme has moved more slowly than AFTA; its main focus is on the rationalisation of the automotive industry.

10 More precisely, the Japan-Singapore agreement is called the 'Agreement between Japan and the Republic of Singapore for a New-Age Economic Partnership' and goes beyond a conventional FTA.

11 These include China with Hong Kong; Hong Kong with New Zealand (and China); South Korea with Chile; Singapore with Australia, the United States, Canada, Mexico and Chile; Thailand with Australia; Australia with the United States (and Singapore and Thailand); and New Zealand with Chile (and Hong Kong).

12 More specifically, Eichengreen and Bayoumi (1999) have found that two groups of economies in the region - one for Japan, Korea and Taiwan, and another for Hong Kong, Indonesia, Malaysia, Singapore and possibly Thailand-are natural groups of countries that are closely integrated. See also Bayoumi and Eichengreen (1994) and Bayoumi et al. (2000).

13 See specifically a paper by Goto (2002) in IIMA(2002) as well as Goto and Kawai (2001).

14 See Kenen (1994), and Hamada and Kawai (1997). 
15 In 1985, when the US dollar was overvalued and the US current account deficits were deemed unsustainable, the foreign exchange market intervention and macroeconomic policies of the United States, Japan and Germany were coordinated in order to guide the US dollar downward, thereby containing the protectionist pressure in the United States. Once the US dollar began to decline rapidly, the G-3 countries attempted to prevent the free fall of the dollar so as to avoid a hard landing of the US economy.

16 See for example Eichengreen (2001).

17 The ADB is also invited for discussions with the finance ministers and/or finance and central bank deputies.

18 See ASEAN+3 Heads of State/Government, 'Joint Statement on East Asia Cooperation,' Manila, 29 November 1999, available at < http://www.aseansec.org/5469.htm>.

19 A task force called the 'ASEAN+3 Study Group to Examine Ways of Enhancing Effectiveness of Economic Reviews and Policy Dialogues' has recommended a two-phase approach. In phase one, the existing arrangement for economic reviews and policy dialogue is strengthened by making the current ERPD Process more credible and subject to serious discussion by finance ministers and their deputies. In phase two, an enhanced ERPD Process will be introduced with support from an independent, professional third party that prepares reviews, assessments and issue papers on emerging problems affecting the region. It has also been proposed that the process should consider soliciting inputs from international financial institutions.

20 Many, but not all, of these economies participated in the Thai financial packageJapan, Australia, China, Hong Kong, Malaysia, Singapore, Brunei, Indonesia and South Korea.

21 See Asian Finance and Central Bank Deputies, 'A New Framework for Enhanced Asian Regional Cooperation to Promote Financial Stability', Manila, 18-19 November 1997, available at $<$ http://www.mof.go.jp/english/if/if000a.htm>.

22 The IMF's Regional Office for Asia and the Pacific provides a technical secretariat function for the MFG.

23 While this forum is considered the most influential for regional central banks, it has its own weaknesses such as irregularity of meeting schedules and lack of continuity. According to Eichengreen (2001), each meeting has a different theme, and themes have ranged over everything from social safety nets to capital flows.

24 A member's swap request for temporary liquidity or balance of payments assistance is confirmed through the agent bank, which informs and consults with the rest of the members to assess and process the request as expeditiously as possible. The agent bank is appointed on a rotation basis in alphabetical order for a term of two years; its primary task is to coordinate ASA implementation. The ASA was activated by Indonesia in 1979, Malaysia in 1980, Thailand in 1980, and the Philippines in 1981 (Henning 2002).

25 More precisely, the term of swap arrangements is for a period of one, two, or three months and renewable, at most once, for up to three months.

26 In principle, there could be 30 bilateral agreements between any one of China, Japan and South Korea, on the one hand, and the 10 ASEAN members on the other, plus three additional agreements among the three non-ASEAN participants. In practice, the main 
agreements have so far been reached (or are close to agreement) among China, Japan and South Korea, as well as between any one of the non-ASEAN countries and the former crisis-affected members of ASEAN.

27 This is the sum of all BSAs, including the amount that Japan committed under the New Miyazawa Initiative - a total of US $\$ 7.5$ billion, or US $\$ 5$ billion with South Korea and US\$2.5 billion with Malaysia-except that two-way BSAs are doubled for calculation purposes. Excluding the amount committed under the New Miyazawa Initiative, the total sum is US $\$ 31.5$ billion.

28 While Indonesia has proposed BSAs with China and South Korea, actual negotiations have yet to begin.

29 Although up to 10 per cent of the BSA drawings under the CMI can be provided for a limited period without an IMF program, subsequent disbursements have to be linked to an IMF program and, therefore, to the government's willingness to meet IMF conditionalities. The participating countries agreed to review the issue of the IMF linkage and other main principles in May 2004.

30 While recognising the benefits of such an arrangement, the group has not agreed on whether the financing should function as the first line of defence, the second line of defence, or both, whether the financing arrangement is for a short term or a medium term, and who should play the coordinating role at the time of a crisis.

31 Some duplications are unavoidable.

32 'Original sin,' as hypothesised by Eichengreen and Hausmann (1999), is a situation where emerging economy residents cannot borrow abroad in domestic currency nor borrow long term, even domestically. Hence domestic banks and corporations tend to face a currency or maturity mismatch or both, thus facing balance-sheet vulnerabilities to sharp changes in exchange rates and/or interest rates.

\section{References}

Bayoumi, Tamim and Barry Eichengreen (1994) 'One Money or Many? Analyzing the Prospects for Monetary Unification in Various Parts of the World', Princeton Studies in Internati onal Finance, No. 76, International Finance Section, Princeton University.

Bayoumi, Tamim, Barry Eichengreen and Paolo Mauro (2000) 'On Regional Monetary Arrangements for ASEAN',J ournal of theJ apaneseand I nternational E conomies, 14: 121-148.

Bird, Graham and Ramkishen S. Rajan (2002) 'The Evolving Asian Financial Architecture', Essays in I nternational E conomics, 226 (February), International Economics Section, Princeton University, Princeton.

Chaipravat, Olarn (2001) 'Towards a Regional Financing Arrangement in East Asia', paper presented to the ADBI/FIMA Symposium, 'From the Asian Financial Crisis of 1997 to a Regional Financing Arrangement' (10 May), Honolulu.

Eichengreen, Barry (1999) Toward a New I nternational Financial Architecture: A Practical PostAsia Agenda (February), Institute for International Economics, Washington DC. 
- - (2001) 'Hanging Together? On Monetary and Financial Cooperation in Asia', mimeo (October), University of California, Berkeley.

Eichengreen, Barry and Tamim Bayoumi (1999) 'Is Asia an Optimum Currency Area? Can It Become One?', in: S. Collignon, J. Pisani-Ferry and Y.C. Park (eds.), Exchange Rate Policies in Emerging Asian Countries, London: Routledge, 347-66.

Eichengreen, Barry and Ricardo Hausmann (1999) 'Exchange Rates and Financial Fragility', NBER Working Paper, No. 7418 (November), National Bureau of Economic Research, Cambridge.

Feldstein, Martin (1998) 'Refocusing the IMF', Foreign Affairs, 77: 20-33.

Frankel, Jeffrey A (1999) 'No Single Currency Regime Is Right for All Countries or at All Times', Essays In International Finance, No. 215 (August), International Finance Section, Princeton University.

French and Japanese Staff, Ministries of Finance (2001) 'Exchange Rate Regimes for Emerging Market Economies', Discussion Paper (14 January), Paris and Tokyo.

Goto, Junichi (2002) 'Economic Preconditions for Monetary Cooperation and Surveillance in East Asia', in Institute for International Monetary Affairs (ed.), Report on theStudy Group on Strengthening Financial Cooperation and Surveillance (February), 1-26, Tokyo.

Goto, Junichi and Masahiro Kawai (2001) 'Macroeconomic Interdependence in East Asia', paper presented to the international conference on 'Economic Interdependence: Shaping Asia-Pacific in the 21st Century' (22-23 March), International Monetary Fund and World Bank, Tokyo.

Hamada, Koichi and Masahiro Kawai (1997) 'International Economic Policy Coordination: Theory and Policy Implications', in Michele U. Fratianni, Dominick Salvatore, and Jurgen von Hagen (eds), Handbook of Comparative Economic Policies, Volume 5, Macroeconomic Policy in Open Economies, Westport and London: Greenwood Press, 87-147.

Henning, Randall C (2002) 'East Asian Financial Cooperation', Pol icy Analyses in I nternational Economics, No. 68 (September), Institute for International Economics, Washington, DC.

IIMA (Institute for International Monetary Affairs) (2000) Workshop on the F ramework for Regional Monetary Stabilisation in East Asia (July), Tokyo.

- - (2002) Report on the Study Group on Strengthening Financial Cooperation and Surveillance: Kobe Research Project (February), commissioned by the Ministry of Finance Japan, Tokyo.

Ito, Takatoshi (2001) 'The Role of the Yen in East Asia', paper presented to the international conference on 'Monetary Outlook on East Asia in an Integrating World Economy' (5-6 September), Chulalongkorn University, Bangkok.

Ito, Takatoshi, Eiji Ogawa and Yuri Sasaki (1999) 'Establishment of the East Asian Fund', Institute for International Monetary Affairs (ed.) Stabilisation of Currencies and Financial Systems in East Asia and International Financial Cooperation, Tokyo.

Kawai, Masahiro (2001) 'Recommending a Currency Basket System for Emerging East Asia', paper presented to the conference on 'Regional Financial Arrangements in East Asia' (12-13 November), Australian National University, Canberra.

- - (2002) 'Exchange Rate Arrangements in East Asia: Lessons from the 1997-98 Currency Crisis', Monetary and E conomi c Studies, Special Edition, 20 (December), Institute for Monetary and Economic Studies, Bank of Japan, 167-204. 
Kawai, Masahiro, Richard Newfarmer and Sergio Schmukler (2001) 'Crisis and Contagion in East Asia: Nine Lessons', Policy Research Working Paper, No. 2610 (June), World Bank, Washington DC.

Kawai, Masahiro and Shinji Takagi (2000) 'Proposed Strategy for a Regional Exchange Rate Arrangement in Post-Crisis East Asia', Policy Research Working Paper, No. 2502 (December), World Bank, Washington DC.

- - (2003) 'Rethinking Capital Controls: The Malaysian Experience', PRI Discussion Paper Series, No. 03A-05 (May), Policy Research Institute, Japanese Ministry of Finance, Tokyo. [A revised version of the paper presented to the international conference on 'Monetary Outlook on East Asia in an Integrating World Economy' (September 5-6, 2001), Chulalongkorn University, Bangkok.]

Kawai, Masahiro and Shujiro Urata (2002) 'Trade and Foreign Direct Investment in East Asia', paper presented to a conference on 'Linkages in East Asia: Implications for Currency Regimes and Policy Dialogue' (23-24 September), Seoul.

Kenen, Peter B. (1994) The International Economy, 3rd edition, Cambridge: Cambridge University Press.

Kenen, Peter B. (2001) Thel nternational Financial Architecture: What's New? What's Missing?, Washington DC: Institute for International Economics.

Krueger, Anne (2002) 'New Approaches to Sovereign Debt Restructuring: An Update on Our Thinking', paper presented to a conference on 'Sovereign Debt Workouts: Hopes and Hazards' (April 1), Institute for International Economics, Washington DC.

McKinnon, Ronald I. (2001) 'After the Crisis, the East Asian Dollar Standard Resurrected', paper presented to the international conference on 'Monetary Outlook on East Asia in an Integrating World Economy' (5-6 September), Chulalongkorn University, Bangkok.

Mundell, Robert (2001) 'Currency Area Formation and the Asian Region', paper presented to the international conference on 'Monetary Outlook on East Asia in an Integrating World Economy' (5-6 September), Chulalongkorn University, Bangkok.

Ogawa, Eiji and Takatoshi Ito (2002) 'On the Desirability of a Regional Basket Currency Arrangement', J ournal of theJ apaneseand International E conomies, 16: 317-334.

Sakakibara, Eisuke and Sharon Smith Yamakawa (2001) 'Regional Integration in East Asia: Challenges and Opportunities', mimeo, Global Security Research Center, Keio University, Tokyo.

Wang, Tongsan (2002) 'Policy Recommendations on How to Strengthen Financial Cooperation in Asia', Institute for International Monetary Affairs (ed.), Report on theStudy Group on Strengthening F inancial Cooperati on and Surveillance(February), 198-211, Tokyo.

Williamson, John (1999a) 'The Case for a Common Basket Peg for East Asian Currencies', in Stefan Collignon, Jean Pisani-Ferry and Yung Chul Park (eds), ExchangeRatePol icies in E merging Asian Countries, London and New York: Routledge, 327-343.

- - (1999b) 'Future Exchange Rate Regimes for Developing East Asia: Exploring the Policy Options', mimeo (May), South Asia Region, World Bank, Washington DC.

World Bank (1998) East Asia: The Road to Recovery, Washington DC.

- - (2000) East Asia: Recovery and Beyond, Washington DC.

Yoshitomi, Masaru and Sayuri Shirai (2000) 'Policy Recommendations for Preventing Another Capital Account Crisis', Technical Background Paper (July 7), Asian Development Bank Institute, Tokyo. 


\section{Previous Pacific Economic Papers}

331 Moving beyond bilateralism? Japan and the Asian monetary fund J ennifer Amyx, September 2002

330 Impact of APEC trade liberalisation on Sino-Australian bilateral trade Yu Sheng, August 2002

329 Intra-industry foreign direct investment and intra-industry trade: a case study of Korea

J ung-Soo Seo, J ong-Soon Kang and Deok-Ki Kim July 2002

328 The effects of the euro on financial markets, activity and structure Werner Studener, June 2002

327 The compatibility of capital controls and financial development: a selective survey and empirical evidence MenzieD. Chinn, May 2002

326 The Basel Process and regional harmonisation in Asia Shinichi Yoshikuni, April 2002

325 Trends in global finance, markets and institutions: some implications for developments in the Asian Region William E. Alexander, March 2002

324 The IMF and East Asia Gordon deBrouwer, February 2002

323 APEC and the new economy Mari Pangestu and Sung-hoon Park, January 2002

322 East Asian steel projections for the 1990s revisited Ben Garvey and Peter Drysdale, December 2001

321 Evidence of shifts in the determinants of the structure of Japanese manaufacturing trade, 1970-95

Peer Drysdaleand Ligang Song, November 2001

320 The services content of Japanese trade Kozo Kiyota, October 2001

319 Changes in the Japanese food sector Ray Trewin et al., September 2001 
318 The changing economic performance and political significance of Japan's agricultural cooperatives Yoshihisa Godo, August 2001

317 Bank and corporate restructuring in crisis-affected East Asia: from systemic collapse to reconstruction

Masahi ro Kawai, July 2001

316 Hot and spicy: ups and downs on the price floor and ceiling at Japanese supermarkets

Kenn Ariga, June 2001

315 China's admittance to the WTO and industrial structural adjustment in the world economy

Christopher Findlay, May 2001

314 'Japan Inc.' in the agricultural sector: reform or regression?

Aurelia GeorgeMulgan, April 2001

313 Encouraging 'democracy' in a Cold War climate: the dual-platform policy approach of Evatt and Labor toward the allied occupation

ChristinedeMatos, March 2001

312 Managing capital flows: a distortions approach

Dominic Wilson, February 2001

311 Old issues in new regionalism

Christopher Findlay, January 2001

310 Trade conflicts between Japan and the United States over market access: the case of automobiles and automotive parts

Masao Satake, December 2000

309 Subregional trading arrangements among APEC economies: managing diversity in the Asia Pacific

Andrew Elek, November 2000

308 Weathering the Asian crisis: the role of China

Yongzheng Yang and Rod Tyers, October 2000

307 The internationalisation of the yen: essential issues overlooked

Tetsuji Murase, September 2000

306 Japan's local governance at the crossroads: the third wave of reform

Purnendra J ain, August 2000 
305 Some key issues for the East Asian food sector M. Honma, R. Trewin, M. Bosworth, R. Stringer and Y. Godo, July 2000 (special volume)

304 Food embargoes against China: their likelihood and potential consequences Yongzheng Yang, June 2000

303 Foreign direct investment and intra-industry trade - the case of the United States Tina Yiping Chen, May 2000

302 Implications of recent Japanese legal reforms Leon Wolff, Veronica Taylor and Akiyoshi Horiuchi, April 2000 (special volume)

301 Toward reform and transparency in Japanese policymaking processes J .A.A. Stockwin, J ennifer Amyx and Gregory Noble, March 2000 (special volume)

300 A way forward for Japanese agriculture? Masayoshi Homna, Ray Trewin, J ennifer Amyxand Allan Rae, February 2000 (special volume)

299 Japanese foreign direct investment in the world economy 1951-1997 Roger Farrell, January 2000

298 The genesis of APEC: Australian-Japanese political initiatives Takashi Terada, December 1999

297 Is shutting Krugman's 'liquidity trap' the answer to Japan's problems? Dominic Wilson, November 1999

296 Japanese government-business collaboration and the operations of Japanese corporations in Asia: A telecommunications case Hidetaka Yoshimatsu, October 1999

295 Free trade champion? Australian views of the US crusade against Japan J ulia Lowell, September 1999

294 Governance and Australian financial institutions Kevin Davis, August 1999

293 The changing climate for foreign direct investment into Japan Peter Drysdale, Ray Trewin, Toshi Naitoand Domi nic Wi Ison, July 1999

292 The Japanese origins of PAFTAD: The beginning of an Asian Pacific economic community

Takashi Terada, June 1999 
291 Not just a question of multilateral free trade: Australia's bilateral trade liberalisation agenda towards Japan

J amieAnderson, May 1999

290 Perspectives on Japanese investment, employment and management in Australia Roger Farrell and Peter Drysdale, April 1999

289 Predicting banking crises: Japan's financial crisis in international comparison Michael Hutchinson and Kathleen McDill, March 1999

288 Japan's financial reform Volume I

Hugh Patrick, Takatoshi Ito, February 1999

287 International trade and environmental policy: how effective is 'eco-dumping'?

Xinpeng Xu, January 1999

286 Open regionalism going global: APEC and the new transatlantic economic partnership Andrew Elek, December 1998

285 Realism and postwar US trade policy J ohn Kunke, November 1998

284 Attracting FDI: Australian government investment promotion in Japan, 1983-96 J amieAnderson, October 1998

283 The Multi-function polis 1987-97: an international failure or innovative local project?

Paul Parker, September 1998

282 Organisation, motivations and case studies of Japanese direct investment in real estate $1985-94$

Roger Farrell, August 1998

281 Japan's approach to Asia Pacific economic cooperation Peter Drysdale, July 1998

280 The politics of telecommunications reform in Japan Hidetaka Yoshimatsu, June 1998

279 Sustainability of growth in the Korean manufacturing sector Chang-Soo Lee, May 1998

278 Export performance of environmentally sensitive goods: a global perspective Xinpeng Xu, April 1998

277 Modelling manufactured exports: evidence for Asian newly industrialising economies Francis In, Pasqual eSgro and J ai-Hyung Yoon, March 1998 
276 Laos in the ASEAN free trade area: trade, revenue and investment implications J ayant Menon, February 1998

275 Globalisation

Heinz Arndt, January 1998

274 The WTO and APEC: What role for China?

Stuart Harris, December 1997

273 The APEC air transport schedule

Christopher Findlay, November 1997

272 Japanese foreign direct investment in real estate 1985-1994

Roger Farrell, October 1997

271 China and East Asia trade policy volume 4: Trade reform and liberalisation in China

Yang Shengming, Zhong Chuanshui, Yongzheng Yang, Feng Lei,

Yiping Huang, and Pei Changhong, September 1997

(Special volume)

\section{Annual subscription rate for twelve issues:}

Individuals A $\$ 65.00$

Institutions $\mathrm{A} \$ 110.00$

\section{Cost for single issues:}

$\mathrm{A} \$ 15.00$

A $\$ 10.00$ (Students)

No postage required within Australia

Available from: Publications Department

Australia-Japan Research Centre

Asia Pacific School of Economics and Management

The Australian National University

Canberra ACT 0200, Australia

Facsimile: (612) 61250767

Telephone:(61 2) 61253780

E-mail:ajrc@anu.edu.au

URL:http://ajrcnet.anu.edu.au/ 